\title{
Imino-phosphine palladium(II) and platinum(II) complexes: Synthesis, molecular structures and evaluation as antitumor agents
}

William M. Motswainyana, Martin O. Onani, Abram M. Madiehe, Morounke Saibu, Ntevheleni Thovhogi and Roger A. Lalancette

\begin{abstract}
The imino-phosphine ligands L1 and L2 were prepared via condensation reaction of 2-(diphenylphosphino) benzaldehyde with substituted anilines and obtained in very good yields. An equimolar reaction of L1 and L2 with either $\mathrm{PdCl}_{2}$ (cod) or $\mathrm{PtCl}_{2}$ (cod) gave new palladium(II) and platinum(II) complexes 14. The compounds were characterized by elemental analysis, IR, ${ }^{1} \mathrm{H}$ and ${ }^{31} \mathrm{P}$ NMR spectroscopy. The molecular structures of 2, 3 and 4 were confirmed by Xray crystallography. All the three molecular structures crystallized in monoclinic $\mathrm{C} 2 / \mathrm{c}$ space system. The coordination geometry around the palladium and platinum atoms in respective structures exhibited distorted square planar geometry at the metal centers. The complexes were evaluated in vitro for their cytotoxic activity against human breast (MCF-7) and human colon (HT-29) cancer cells, and they exhibited growth inhibitory activities and selectivity that were superior to the standard compound cisplatin.
\end{abstract}

\section{Introduction}

Most of the chemistry of imino-phosphine compounds originated from the discovery of the ligand 2-(diphenylphosphino)benzaldehyde by Rauchfuss et al. in 1982 [1]. This compound has since been preferred as a main precursor in the preparation of many derivatives of imino-phosphine ligands. Consequently, several metal complexes containing imino-phosphine ligands started to emerge in the early 1990s [2-4]. Since then, hetero-dentate ligands with hard and soft P$\mathrm{N}$ donor atoms with interesting properties have been generated and continue to attract interest to date [5-8]. Upon coordination to transition metals, the hard and soft combination creates asymmetry in the metal orbitals, which subsequently regulates the reactivity of a complex bearing these ligands [5]. An illustration of this effect is demonstrated by the observed difference in the trans-influence of the phosphorus donor atom compared to either nitrogen or oxygen [5]. 
Despite the preparation of several phosphine based complexes, they remain least explored for their potential to inhibit tumor growth. The likely advanced reason could be their susceptibility to oxidation, which makes them very difficult to handle in air [9]. The few existing reports on antitumor studies are based on phosphine gold(I) complexes [10-13]. For instance, triethylphosphine $(2,3,4,6-$ tetra-O-acetyl- $\beta$-1-D-thiopyranosato-S)gold(I), commonly known as auranofin is the first phosphine complex that showed significant cytotoxicity about two decades ago [10]. In the auranofin molecule, the neutral triethylphosphine ligand confers membrane permeability while the mono-anionic tetraacetylthioglucose is displaced quite rapidly in vivo. The compound was proved to possess in vitro cytotoxic potency against melanoma (B16) and leukemia (P388) cancer cell lines [10]. Recently, additional in vitro studies have shown that auranofin was able to overcome cisplatin resistance in human ovarian cancer cells [11]. In particular, it was found that auranofin causes an alteration of the redox state of the cell, leading to an increased production of hydrogen peroxide and oxidation of the components of the thioredoxin system, therefore creating suitable conditions for enhanced apoptosis [11]. Other gold(I) phosphine complexes which have also shown great potential to induce apoptosis on tumor cell lines include the 1,2-[bis(diphenylphosphino)]ethane gold(I) [12] and tetrakis[tris(hydroxyl-methyl)]phosphine gold(I) chloride [13]. The work of Bacchi et al. has mechanistically demonstrated that an imino-phosphine ligand which forms a 6-membered ring around the metal center stabilizes the complex during biological investigations, while the steric bulkiness of the ligand manipulates the activity of the complex against cisplatin resistant cells [14]. In the context of this background, we report the synthesis and full characterization

of sterically congested mononuclear imino-phosphine palladium(II) and platinum(II) complexes containing substituted aniline. Antitumor activity of these complexes has been investigated in vitro against MCF-7 and HT-29 cancer cell lines and the results are herein discussed. This work could add up to the current drive in the design and development of platinum group metal (PGM) complexes in anticancer therapy.

\section{Experimental}

2.1. Materials and instrumentation

All reactions were carried out under nitrogen atmosphere using a dual vacuum/nitrogen line and standard Schlenk techniques unless stated otherwise. Solvents were dried and purified by heating at reflux under nitrogen in the presence of a suitable drying agent. All the re-agents and starting materials were purchased from Sigma-Aldrich and were used without any further purification. The palladium metal pre-cursor $\mathrm{PdCl}_{2}(\operatorname{cod})(\operatorname{cod}=$ cyclooctadiene) was prepared by following literature method [15].

\section{http://repository.uwc.ac.za}


2.2.1 (2-Diphenylphosphino-benzylidene)-2-methylphenylen-amine (L1)

To a solution of 2-(diphenylphosphino)benzaldehyde $(0.279 \mathrm{~g}, 0.961 \mathrm{mmol})$ in $\mathrm{CH}_{2} \mathrm{Cl}_{2}(10 \mathrm{ml})$ in a Schlenk tube was added 2-methylaniline (0.103 $\mathrm{g}, 0.961$ mmol) dropwise. Anhydrous magnesium sulfate $(\sim 0.5 \mathrm{~g})$ was added to the Schlenk tube and the reaction was stirred at room temperature for $20 \mathrm{~h}$. The resulting yellow mixture was filtered to obtain a yellow solution, which gave yellow oil upon evaporation of the solvent. Yield: $0.2990 \mathrm{~g}$ (82\%); IR (nujol $\left.\mathrm{cm}^{-1}\right)$; $\mathrm{v}\left(\mathrm{C} \_\mathrm{N}\right.$ imine $)$ 1622, $\mathrm{v}\left(\mathrm{C} \_\mathrm{C}\right.$ phenyl) 1593, 1585, 1505; v $(\mathrm{P} \backslash \mathrm{Ph})$ 1435; ${ }^{1} \mathrm{H}$ NMR (2OO MHz, $\mathrm{CDCl}_{3}$ ): $\delta 8.99\left(\mathrm{~d}, 1 \mathrm{H}, \mathrm{J}=5.2, \backslash \mathrm{CH} \_\mathrm{N}\right.$ ); 8.27, 6.91-7.67 (m, 12H, phenyl); 6.46 (t, 6H, J = 7.6, phenyl); 1.27 (s, 3H, $\left.\mathrm{CH}_{3}\right) ; 31 \mathrm{P}$ NMR (161.9 Hz, $\left.\mathrm{CDCl}_{3}\right) \delta-13.96(\mathrm{~s})$; Anal. Calcd for $\mathrm{C}_{2} 6 \mathrm{H}_{22} \mathrm{NP}: \mathrm{C}, 82.30$; H, 5.84; N, 3.69; Found: C, 82.04; H, $5.93 ; \mathrm{N}, 3.55$.

\subsection{2 (2-Diphenylphosphino-benzylidene)-2,6-dimethylphenylen-amine (L2)}

The ligand was synthesized according to the procedure described for L1 using 2(diphenylphosphino)benzaldehyde (0.2752 g, $0.948 \mathrm{mmol}$ ) and 2,6-dimethylaniline (0.1149 g, $0.948 \mathrm{mmol}$ ). Yellow oil was obtained. Yield: $0.2984 \mathrm{~g}$ (80\%); IR (nujol $\left.\mathrm{cm}^{-1}\right)$; v(C_N imine) 1632, v(C_C phenyl) 1590, 1562, 1502; v(P\Ph) 1434; ${ }^{1} \mathrm{H}$ NMR (2O0 MHz, $\left.\mathrm{CDCl}_{3}\right): \delta 8.88\left(\mathrm{~d}, 1 \mathrm{H}, \mathrm{J}=5.2, \backslash \mathrm{CH} \_\mathrm{N}\right) ; 8.30,6.88-7.94(\mathrm{~m}$, 12H, phenyl); 6.73 (t, 6H, J = 7.4, phenyl); $1.83\left(\mathrm{~s}, 6 \mathrm{H}^{\mathrm{C}} \mathrm{CH}_{3}\right) ; 31 \mathrm{P}$ NMR (161.9 Hz, $\left.\mathrm{CDCl}_{3}\right) \delta-14.00(\mathrm{~s})$; Anal. Calcd for $\mathrm{C}_{27} \mathrm{H}_{24} \mathrm{NP}$ : C, 82.42; H, 6.15; N, 3.56; Found: C, 82.63; H, 5.98; N, 3.82 .

\subsection{Synthesis of metal complexes}

\subsubsection{Dichloro[(2-diphenylphosphino-benzylidene)-2-methylphenylen- amine] palladium(II) (1)}

To a suspension of $\mathrm{PdCl}_{2}$ (cod) $(0.0482 \mathrm{~g}, 0.169 \mathrm{mmol})$ in $\mathrm{CH}_{2} \mathrm{Cl}_{2}$ (2O ml) was added a solution of $\mathrm{L} 1$ (0.0635 $\mathrm{g}, 0.167 \mathrm{mmol})$ in $\mathrm{CH}_{2} \mathrm{Cl}_{2}(5 \mathrm{ml})$. The reaction was stirred at room temperature for $6 \mathrm{~h}$, resulting in a yellow solution. The solution was concentrated before excess hexane was added to precipitate out a yellow solid. The precipitate was filtered, washed with hexane $(2 \times 5 \mathrm{ml})$ and dried under vacuum. Suitable crystals for X-ray crystallography were grown by slow evaporation of $\mathrm{CH}_{3} \mathrm{CN}$ solution of the complex. [16]. Yield: $0.0697 \mathrm{~g}$ (75\%); IR (nujol $\mathrm{cm}^{-1}$ ); v(C_N imine) 1614, v(C_C phenyl) 1585, 1560, 1502; ${ }^{1} \mathrm{H}$ NMR (200 $\mathrm{MHz}_{\mathrm{CDCl}}$ ): $\delta 8.67\left(\mathrm{~s}, 1 \mathrm{H}, \backslash \mathrm{CH} \_\mathrm{N}\right) ; 8.20,6.92-7.96(\mathrm{~m}, 12 \mathrm{H}$, phenyl); $5.77(\mathrm{~d}, 6 \mathrm{H}$, $\mathrm{J}=1.8$, phenyl); 2.14 (d, $3 \mathrm{H}, \mathrm{J}=2.2, \mathrm{CH}_{3}$ ); 31 $\mathrm{P} \mathrm{NMR}\left(161.9 \mathrm{~Hz}, \mathrm{CDCl}_{3}\right) \delta 30.47(\mathrm{~s}) ;$ Anal. Calcd for $\mathrm{C}_{2} 6 \mathrm{H}_{22} \mathrm{Cl}_{2} \mathrm{NPPd}$ : C, 56.09; H, 3.98; N, 2.52; Found: C, 55.83; H, 4.22; N, 2.77 .

\section{http://repository.uwc.ac.za}


2.3.2 Dichloro-[2-diphenylphosphino-benzylidene)-2,6-dimethylphenylenamine] palladium(II) (2)

The compound was synthesized according to the procedure used in 1, using $\mathrm{PdCl}_{2}$ (cod) (0.0424 g, $0.149 \mathrm{mmol}$ ) and L2 (0.0561 g, $0.143 \mathrm{mmol}$ ). Suitable crystals for X-ray crystallography were grown by the slow diffusion of hexane into a solution of the complex in $\mathrm{CH}_{2} \mathrm{Cl}_{2}$. Yield: $0.0567 \mathrm{~g}$ (72\%); IR (nujol cm${ }^{-1}$ ); $v\left(\mathrm{C} \_\mathrm{N}\right.$ imine $)$ 1610, v(C_C phenyl) 1586, 1559, 1501; ${ }^{1} \mathrm{H}$ NMR (200 MHz, $\mathrm{CDCl}_{3}$ ): $\delta$ $8.62\left(\mathrm{~s}, 1 \mathrm{H}, \backslash \mathrm{CH} \_\mathrm{N}\right) ; 8.22,6.89-7.92(\mathrm{~m}, 12 \mathrm{H}$, phenyl); $5.75(\mathrm{~d}, 6 \mathrm{H}, \mathrm{J}=1.6$, phenyl); 2.15 (d, 6H, J = 2.2, $\mathrm{CH}_{3}$ ); $31 \mathrm{P}$ NMR (161.9 Hz, $\mathrm{CDCl}_{3}$ ) $\delta$ 27.68(s); Anal. Calcd for $\mathrm{C}_{27} \mathrm{H}_{24} \mathrm{Cl}_{2} \mathrm{NPPd}$ : C, 56.81; H, 4.24; N, 2.45; Found: C, 57.01; H, 4.30; N, 2.29.

\subsubsection{Dichloro-[(2-diphenylphosphino-benzylidene)-2-methylphenylen- amine] platinum(II) (3)}

The compound was synthesized according to the procedure used in 1, using $\mathrm{PtCl}_{2}$ (cod) (0.0388 g, $0.131 \mathrm{mmol}$ ) and $\mathrm{L} 1$ (0.0479 g,0.126 mmol). Suitable crystals for X-ray crystallography were grown by the slow diffusion of hexane into a solution of the complex in $\mathrm{CH}_{2} \mathrm{Cl}_{2}$. Yield: $0.0618 \mathrm{~g}$ (76\%); IR (nujol cm${ }^{-}$ 1); 1607, v(C_C phenyl) 1588, 1560, 1502; ${ }^{1} \mathrm{H}$ NMR (200 $\mathrm{MHz}, \mathrm{CDCl}_{3}$ ): $\delta 8.88$ (s, $\left.1 \mathrm{H}, \backslash \mathrm{CH} \_\mathrm{N}\right) ; 8.17,6.95-7.86(\mathrm{~m}, 12 \mathrm{H}$, phenyl); $5.75(\mathrm{~s}, 6 \mathrm{H}$, phenyl); 2.14 (d, $\left.3 \mathrm{H}, \mathrm{J}=2.4, \mathrm{CH}_{3}\right)$; ${ }^{31} \mathrm{P}$ NMR $\left(161.9 \mathrm{~Hz}, \mathrm{CDCl}_{3}\right) \delta 28.41(\mathrm{~s})$; Anal. Calcd for $\mathrm{C}_{26} \mathrm{H}_{22} \mathrm{Cl}_{2} \mathrm{NPPt}$ : C, 48.38; H, 3.44; N, 2.17; Found: C, 48.26; H, 3.19; N, 2.42.

\subsubsection{Dichloro-[2-diphenylphosphino-benzylidene)-2,6-dimethylphenylen- amine] platinum(II) (4)}

The compound was synthesized according to the procedure used in 1, using $\mathrm{PtCl}_{2}$ (cod) (0.0476 g, $0.161 \mathrm{mmol}$ ) and $\mathrm{L} 2$ (0.0609 g, $0.155 \mathrm{mmol}$ ). Suitable crystals for X-ray crystallography were grown by the slow diffusion of hexane into a solution of the complex in $\mathrm{CH}_{2} \mathrm{Cl}_{2}$. Yield: $0.0756 \mathrm{~g}$ (74\%); IR (nujol cm$\left.{ }^{1}\right)$; 1603, v(C_C phenyl) 1583, 1561, 1503; ${ }^{1} \mathrm{H}$ NMR (200 $\mathrm{MHz}, \mathrm{CDCl}_{3}$ ): $\delta 8.87$ (s, 1H, \CH_N); 8.20, 6.76-7.89 (m, 12H, phenyl); 5.74 (s, 6H, phenyl); 2.13 $\left(\mathrm{d}, 6 \mathrm{H}, \mathrm{J}=2.2, \mathrm{CH}_{3}\right) ; 31 \mathrm{P} \mathrm{NMR}\left(161.9 \mathrm{~Hz}, \mathrm{CDCl}_{3}\right) \delta 26.23(\mathrm{~s})$; Anal. Calcd for $\mathrm{C}_{27} \mathrm{H}_{24} \mathrm{Cl}_{2} \mathrm{NPPt}$ : C, 49.18; H, 3.67; N, 2.12; Found: C, 49.4O; H, 3.72; N, 2.33 .

\subsection{Molecular structures of 2, 3 and 4}

Single crystals of complexes 2, 3 and 4 suitable for X-ray crystallography were grown by various crystallization techniques. X-ray diffraction data for the compound was collected on a Bruker KAPPA APEX II DUO diffractometer using graphitemonochromated Mo-Ka radiation $(X=0.71073 \AA)$. The crystal structures were solved by direct methods using SHELX [17] and refined by full-matrix least-

\section{http://repository.uwc.ac.za}


squares methods based on $\mathrm{F}^{2}$ [17] using SHELX [17] and using the graphics interface program ORTEP-3 for Windows $[18,19]$.

\subsection{Cytotoxicity determination \\ 2.5.1 Cell culture}

Cancerous cell lines MCF-7 and HT-29 were cultured in DMEM medium with GlutaMAX-1, 10\% (v/v) fetal calf serum, and $0.2 \%(\mathrm{v} / \mathrm{v})$ streptomycin-penicillin. All cell culture reagents were supplied by Invitrogen Ltd. All cell lines were maintained at $37^{\circ} \mathrm{C}$ in an atmosphere of $5 \% \mathrm{CO}_{2}$. Cells were plated in 96 well tissue culture plates at a cell density of $2.4 \times 10^{4}$ cells per well or in 24 well tissue culture plates at a cell density of $1 \times 105$ cells per well. After $24 \mathrm{~h}$ the medium was replaced with medium containing the test compounds.

\subsubsection{MTT assay}

The 3-(4,5-dimethyl-2-thiazolyl)-2,5-diphenyl-2H-tetrazolium bromide (MTT) assay measures the amount of MTT reduction by the mitochondrial dehydrogenase based on the ability of live cells to incorporate and bind the dye.

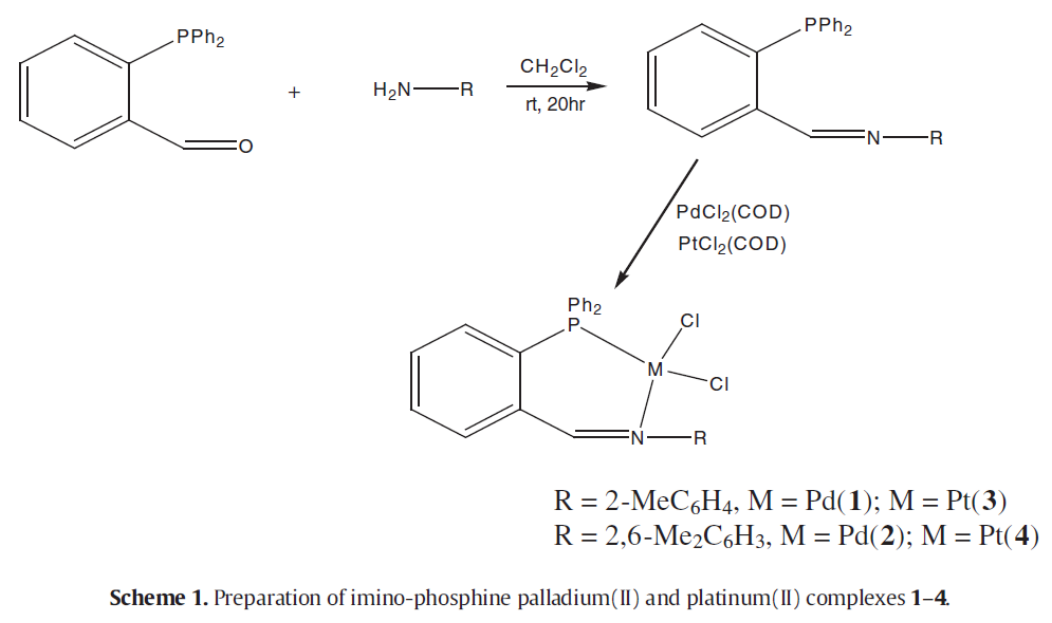

The cells were plated in 96-well tissue plates at a density of $2.4 \times 10^{4}$ cells $/ \mathrm{ml}$ per well. Cells were then treated with various concentrations of the complexes (100 to $10 \mu \mathrm{M}$ ) after which they were incubated for $24 \mathrm{~h}$. Triplicate wells were established for each concentration. Just $5 \mathrm{~h}$ before the elapse of $24 \mathrm{~h}, 10 \mu \mathrm{l}$ of 5 $\mathrm{mg} / \mathrm{ml}$ MTT solution was added to each well and the plates were further incubated for $4 \mathrm{~h}$. At the end of the incubation period, the media was removed from each well and replaced with $50 \mu \mathrm{l}$ of DMSO. The plates were shaken on a rotating shaker for $10 \mathrm{~min}$ before taking readings at $560 \mathrm{~nm}$ using a microplate reader.

\section{http://repository.uwc.ac.za}




\subsubsection{APOPercentage ${ }^{\mathrm{TM}}$ apoptosis assay}

This assay helps with detection and quantification of apoptosis. Cells were treated for $24 \mathrm{~h}$ with increasing concentrations $(6.25-100 \mu \mathrm{M})$ of the complexes and $10 \mu \mathrm{M}$ cisplatin (positive control) and incubated for a further $24 \mathrm{~h}$, after which the cells were harvested. A minimum of 10,000 cells per sample was acquired and analyzed on a FASCan ${ }^{\mathrm{TM}}$ (Becton Dickinson) instrument using CELLQuest PRO software (BD Biosciences Pharmingen). All the experiments were done in triplicate.

\section{Results and discussion}

\subsection{Synthesis of ligands and metal complexes}

The imino-phosphine ligands L1 and L2 were prepared via a Schiff base condensation reaction of 2-(diphenylphosphino)benzaldehyde with substituted anilines (Scheme 1). The ligands were obtained as light brown oil in good yields of over 80\%. Imino-phosphine compounds are known for their susceptibility to oxidation, therefore an oxygen free technique was used to prevent the ligands from possible contamination with phosphine oxide. Ligand L1 is reported for the first time to the best of our knowledge. L2 has been reported by other research groups $[5,20,21]$ but it was independently prepared and characterized by us. The ligands were reacted with either $\mathrm{PdCl}_{2}(\mathrm{cod})$ or $\mathrm{PtCl}_{2}(\mathrm{cod})$ to give the corresponding new imino-phosphine palladium(II) and platinum(II) complexes 14 (Scheme 1). The complexes were obtained as yellow solids in good yields averaging $70 \%$ after filtration and evaporation of solvents.

All the compounds were characterized by a combination of elemental analysis, IR, ${ }^{31} \mathrm{P}$ and ${ }^{1} \mathrm{H}$ NMR spectroscopy. In the IR spectra of the ligands, imine formation was confirmed by strong absorption bands at 1622 and $1632 \mathrm{~cm}^{-1}$ for L1 and L2 respectively. These absorption frequencies are consistent with those of related imino-phosphine compounds [22-25]. Coordination of the ligands was further confirmed by lower absorption bands between 1603 and $1614 \mathrm{~cm}^{-1}$, which is a typical characteristic of metal coordinated imines [2225].

In the ${ }^{1} \mathrm{H}$ NMR spectra of the ligands, doublet peaks were observed at $8.99 \mathrm{ppm}$ and 8.88 ppm for L1 and L2 respectively due to (HC_N), thus confirming a Schiff base condensation reaction. The doublet suggests that the imine proton had coupled to the phosphorus by pointing towards the phosphorus lone pair [22,25-28]. The ${ }^{31} \mathrm{P}$ NMR spectra of the ligands showed an upfield characteristic singlet at around $-\mathbf{1 4 . 0 0} \mathrm{ppm}$ for uncoordinated phosphorus [22]. Coordination of the ligands was confirmed in the ${ }^{1} \mathrm{H}$ NMR spectra of complexes, which showed singlet peaks in the upfield region $8.62-8.88 \mathrm{ppm}$.

\section{http://repository.uwc.ac.za}




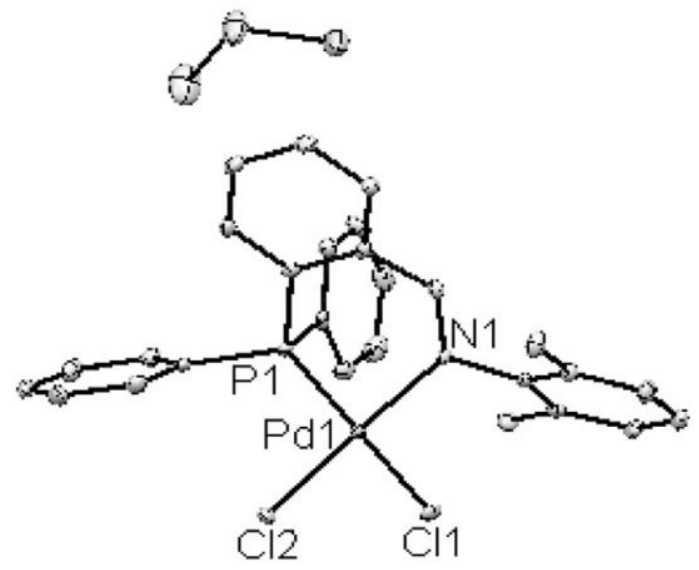

Fig. 1. X-ray crystal structure of complex 2.

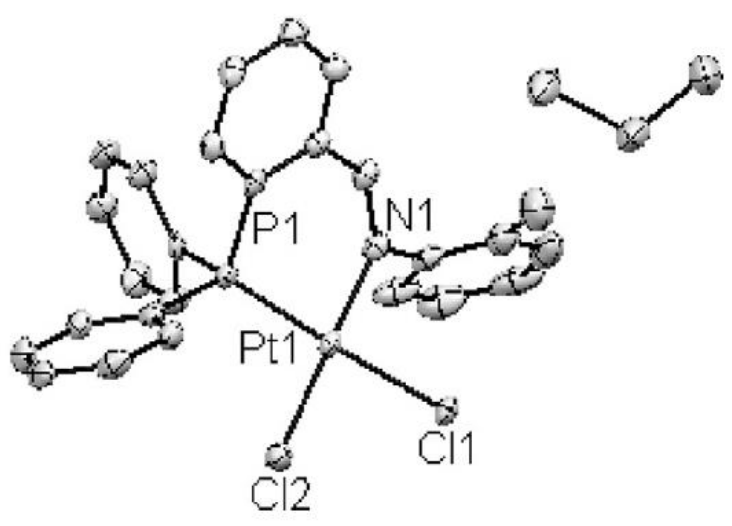

Fig. 2. X-ray crystal structure of complex 3.
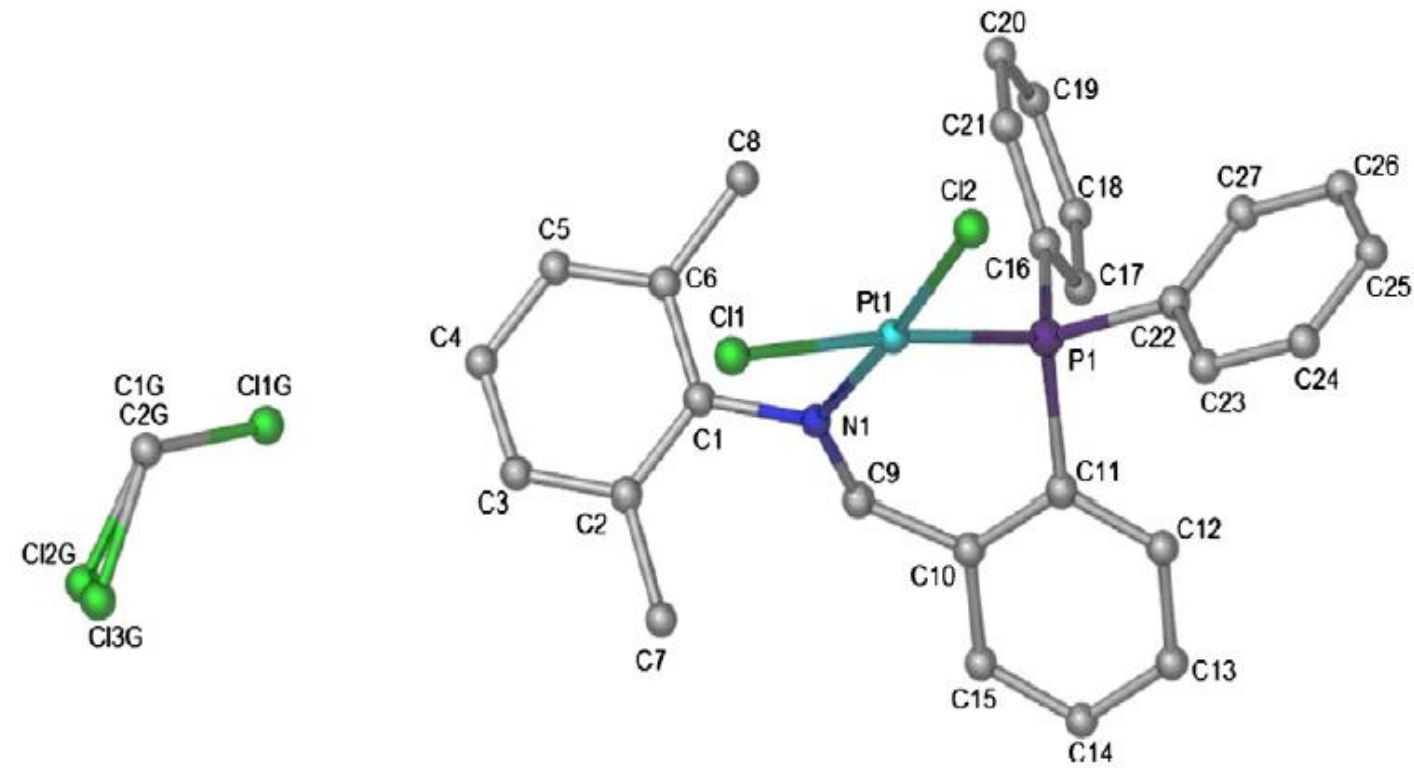

Fig. 3. X-ray crystal structure of complex 4.

http://repository.uwc.ac.za 
This provided evidence for strong coordination of the imine nitrogen to the palladium or platinum metal center. These chemical shift values generally reflect an upfield shift compared to their corresponding ligands, a phenomenon which is consistent with co-ordinated imines [29,30]. The ${ }^{31} \mathrm{P}$ NMR spectra of the complexes also revealed a downfield shift in the phosphorus peak to around $30.00 \mathrm{ppm}$, confirming coordination of the phosphorus to the metal center [25,28].

\subsection{Single crystal $X$-ray diffraction studies}

The molecular structures of complexes 2, 3 and 4 were determined by X-ray diffraction studies to confirm their structures. The molecular structures of the complexes are shown in Figs. 1, 2 and 3 respectively. Crystallographic data and refinement residuals are summarized in Table 1 , while selected bond lengths and bond angles are found in Table 2.

The three molecules crystallize in the monoclinic space group $\mathrm{C} 2 / \mathrm{c}$. The palladium and platinum atoms are four coordinated via the $\mathrm{P}$ and $\mathrm{N}$ atoms of the iminophosphine ligand and two chloride anions, generating a distorted square planar coordination geometry around the metal center. The bond angles $\mathrm{N}(1) \backslash \mathrm{Pd}(1) \backslash \mathrm{P}(1) \quad\left(89.14(5)^{\circ}\right) \quad$ and $\mathrm{Cl}(2) \backslash \mathrm{Pd}(1) \backslash \mathrm{Cl}(1) \quad\left(91.039(18)^{\circ}\right)$ in 2 , $\mathrm{N}(1) \backslash \mathrm{Pt}(1) \backslash \mathrm{P}(1) \quad\left(88.14(13)^{\circ}\right)$ and $\mathrm{Cl}(2) \backslash \mathrm{Pt}(1) \backslash \mathrm{Cl}(1) \quad\left(89.06(5)^{\circ}\right)$ in 3 and $\mathrm{N}(1) \backslash \mathrm{Pt}(1) \backslash \mathrm{P}(1)\left(89.25(7)^{\circ}\right)$ and $\mathrm{Cl}(2) \backslash \mathrm{Pt}(1) \backslash \mathrm{Cl}(1)\left(89.38()^{\circ}\right)$ in 4 describe the observed distorted square planar geometry, while also indicating some ring strain induced by the chelating nature of the bidentate ligand.

Table 2

Selected bond lengths and bond angles for complexes 2, 3 and 4.

\begin{tabular}{lll}
\hline Complex & Bond length $(\AA)$ & Bond angle $\left(^{\circ}\right)$ \\
\hline $\mathbf{2}$ & $\mathrm{Pd}(1)-\mathrm{N}(1) 2.0634(18)$ & $\mathrm{N}(1)-\mathrm{Pd}(1)-\mathrm{P}(1) 89.14(5)$ \\
& $\mathrm{Pd}(1)-\mathrm{P}(1) 2.2213(5)$ & $\mathrm{N}(1)-\mathrm{Pd}(1)-\mathrm{Cl}(1) 89.77(5)$ \\
& $\mathrm{Pd}(1)-\mathrm{Cl}(1) 2.3628(5)$ & $\mathrm{P}(1)-\mathrm{Pd}(1)-\mathrm{Cl}(2) 90.675(19)$ \\
3 & $\mathrm{Pd}(1)-\mathrm{Cl}(2) 2.2841(5)$ & $\mathrm{Cl}(2)-\mathrm{Pd}(1)-\mathrm{Cl}(1) 91.039(18)$ \\
& $\mathrm{Pt}(1)-\mathrm{N}(1) 2.041(5)$ & $\mathrm{N}(1)-\mathrm{Pt}(1)-\mathrm{P}(1) 88.14(13)$ \\
& $\mathrm{Pt}(1)-\mathrm{P}(1) 2.2030(13)$ & $\mathrm{N}(1)-\mathrm{Pt}(1)-\mathrm{Cl}(1) 89.80(13)$ \\
& $\mathrm{Pt}(1)-\mathrm{Cl}(1) 2.3631(13)$ & $\mathrm{P}(1)-\mathrm{Pt}(1)-\mathrm{Cl}(2) 93.19(5)$ \\
$\mathbf{4}$ & $\mathrm{Pt}(1)-\mathrm{Cl}(2) 2.2891(14)$ & $\mathrm{Cl}(2)-\mathrm{Pt}(1)-\mathrm{Cl}(1) 89.06(5)$ \\
& $\mathrm{Pt}(1)-\mathrm{N}(1) 2.044(2)$ & $\mathrm{N}(1)-\mathrm{Pt}(1)-\mathrm{P}(1) 89.25(7)$ \\
& $\mathrm{Pt}(1)-\mathrm{P}(1) 2.2099(8)$ & $\mathrm{N}(1)-\mathrm{Pt}(1)-\mathrm{Cl}(1) 89.32(7)$ \\
& $\mathrm{Pt}(1)-\mathrm{Cl}(1) 2.3624(7)$ & $\mathrm{P}(1)-\mathrm{Pt}(1)-\mathrm{Cl}(2) 92.43(3)$ \\
& $\mathrm{Pt}(1)-\mathrm{Cl}(2) 2.2889(7)$ & $\mathrm{Cl}(2)-\mathrm{Pt}(1)-\mathrm{Cl}(1) 89.38(3)$ \\
\hline
\end{tabular}




\begin{tabular}{|c|c|c|c|}
\hline Crystallographic data & 2 & 3 & 4 \\
\hline Empirical formula & $\mathrm{C}_{27} \mathrm{H}_{24} \mathrm{Cl}_{2} \mathrm{NPPd} \cdot \mathrm{CH}_{2} \mathrm{Cl}_{2}$ & $\mathrm{C}_{26} \mathrm{H}_{22} \mathrm{Cl}_{2} \mathrm{NPPt} \cdot \mathrm{CH}_{2} \mathrm{Cl}_{2}$ & $\mathrm{C}_{28} \mathrm{H}_{26} \mathrm{Cl}_{4} \mathrm{NPPt}$ \\
\hline Formula weight & 655.67 & 730.33 & 744.36 \\
\hline Temperature (K) & 100 & 100 & 173 \\
\hline Crystal system & Monoclinic & Monoclinic & Monoclinic \\
\hline Space group & $C 2 / c$ & $C 2 / c$ & $C 2 / c$ \\
\hline \multicolumn{4}{|l|}{ Unit cell dimensions } \\
\hline$a(\AA)$ & $33.5076(6)$ & $33.1988(8)$ & $33.532(3)$ \\
\hline$b(\AA)$ & $9.7724(2)$ & $9.7768(2)$ & $9.8773(7)$ \\
\hline$\beta\left({ }^{\circ}\right)$ & $123.885(1)$ & $125.568(1)$ & $123.941(1)$ \\
\hline$V\left(\AA^{3}\right)$ & $5488.35(17)$ & $5396.5(2)$ & $5573.3(7)$ \\
\hline $\mathrm{Z}$ & 8 & 8 & 8 \\
\hline $\mathrm{D}_{\text {cal }}\left(\mathrm{Mg} \mathrm{m}^{-3}\right)$ & 1.587 & 1.798 & 1.774 \\
\hline $\mathrm{F}(000)$ & 2640 & 2832 & 2896 \\
\hline Absorption coefficient $\left(\mathrm{mm}^{-1}\right)$ & 9.73 & 14.06 & 5.50 \\
\hline Crystal size $\left(\mathrm{mm}^{3}\right)$ & $0.44 \times 0.12 \times 0.08$ & $0.37 \times 0.10 \times 0.10$ & $0.07 \times 0.07 \times 0.05$ \\
\hline Number of data collected & 4990 & 4915 & 5967 \\
\hline Number of parameters refined & 318 & 308 & 328 \\
\hline Theta range for data collection & 2.8 to $71.8^{\circ}$ & 4.3 to $71.8^{\circ}$ & 1.5 to $26.8^{\circ}$ \\
\hline Goodness-of-fit on $F^{2}$ & 1.08 & 1.22 & 1.02 \\
\hline Largest diff. peak and hole & 0.87 and $-0.71 \mathrm{e} \cdot \AA^{-3}$ & 1.80 and $-1.59 \mathrm{e} \cdot \AA^{-3}$ & 0.51 and $-0.52 \mathrm{e} \cdot \AA^{-3}$ \\
\hline
\end{tabular}

Table 3

Cytotoxic activities and selectivity index for the free ligand and complexes 1-4 tested against MCF-7 and HT-29 cancer cell lines.

\begin{tabular}{lllll}
\hline $\mathrm{IC}_{50}(\mu \mathrm{M})^{\mathrm{a}}$ & & & & \\
\hline Compound & $\mathrm{MCF}-7$ & $\mathrm{SI}^{\mathrm{b}}$ & $\mathrm{HT}-29$ & $\mathrm{Sl}^{\mathrm{b}}$ \\
\hline L2 & $>100$ & 0.0 & $>100$ & 0.0 \\
Palladium(II) complexes & & & & \\
$\quad 1$ & $43.5 \pm 0.25$ & 2.29 & $48 \pm 0.19$ & 2.08 \\
2 & $28.5 \pm 0.21$ & 2.87 & $29 \pm 0.15$ & 2.81 \\
Platinum(II) complexes & & & & \\
3 & $87 \pm 0.03$ & 1.0 & $55 \pm 0.31$ & 1.6 \\
4 & $86 \pm 0.38$ & 1.1 & $50 \pm 0.41$ & 1.8 \\
Cisplatin & $100 \pm 0.20$ & 0.94 & $100 \pm 0.51$ & 0.94 \\
\hline
\end{tabular}

a The concentration of the complex required to inhibit cell growth by $50 \%$. The experiments were done in triplicate. Data were expressed as the mean of the triplicate. $\mathrm{IC}_{50}>100 \mu \mathrm{M}$ is considered to be inactive.

b Selectivity index. SI $>1$ indicates high selectivity.

The $\operatorname{Pd}(1) \backslash \mathrm{C} 1(2)$ bond length of 2.2841(5) $\AA$ and $\operatorname{Pt}(1) \backslash \mathrm{C} 1(2)$ bond length of 2.2891(14) $\AA$ are in good agreement with the average $\mathrm{Pd} \backslash \mathrm{Cl}$ and $\mathrm{Pt} \backslash \mathrm{Cl}$ bond distances respectively for known complexes [31-33]. The average bond lengths $\operatorname{Pd}(1) \backslash N(1)$ and $\operatorname{Pd}(1) \backslash P(1)$ in 2 and $P t(1) \backslash N(1)$ and $P t(1) \backslash P(1)$ in 3 and 4 also compare well with the literature values [32-35]. There is a detectable transinfluence as evidenced in bond lengths $\mathrm{Pd}(1) \backslash \mathrm{Cl}(1)$ and $\mathrm{Pt}(1) \backslash \mathrm{Cl}(1)$ trans- to the phosphorus atom which are significantly longer than their corresponding bond lengths trans- to the amine. This reflects the stronger trans-influence of the diphenylphosphino group compared to an amine [28].

\section{http://repository.uwc.ac.za}




\subsection{Cytotoxicity studies}

The main aim of this study was to evaluate imino-phosphine palladium(II) and platinum(II) complexes as possible antitumor agents. The antitumor investigation of these complexes was motivated by two reasons: firstly the complexes are bulky, and the steric bulk around the coordinated metal atom has been perceived as a perfect strategy to prevent axial approach to the metal atom, which would inhibit the formation of a five-coordinate intermediate that would lead to a ligand substitution [36]. The steric hindrance would also permit high selectivity to DNA binding [37-39]. Secondly, chelating bidentate ligands have been viewed as important in preventing trans-labilization and undesired displacement of the ligands by bio-molecules [40]. Furthermore, iminophosphine complexes have been less explored for their potential to inhibit tumor growth possibly due to their susceptibility to oxidation.

The free imino-phosphine ligand L2 and palladium(II) and platinum(II) complexes 1-4 were evaluated for their potential to exert cytotoxicity on highly invasive human breast (MCF-7) and human colon (HT-29) tumor cell lines using MTT assay with minor modifications [41-43]. The compounds were first solubilized in DMSO. The solvent is regarded as highly effective in accelerating the rate of chloride displacement from a complex [44]. The results, expressed as concentration of the complex required to inhibit tumor cell growth by $50 \%\left(\mathrm{IC}_{50}\right)$ are summarized in Table 3. Cytotoxicity of cisplatin was evaluated under the same experimental conditions for comparison. The selectivity index (SI), which gives the cytotoxicity safety of the complexes was calculated from $\mathrm{IC}_{50}$ values obtained from the induced significant levels of apoptosis in all the cell lines. The imino-phosphine ligand L2 was also evaluated to assess whether free imino-phosphine ligands could exert cytotoxicity on cancer cells, and the ligand did not show any appreciable activity ( $\mathrm{IC}_{50} \mathrm{~N} 100 \mu \mathrm{M}$ ). Therefore, any observed significant activity could be attributed to the complexes. 


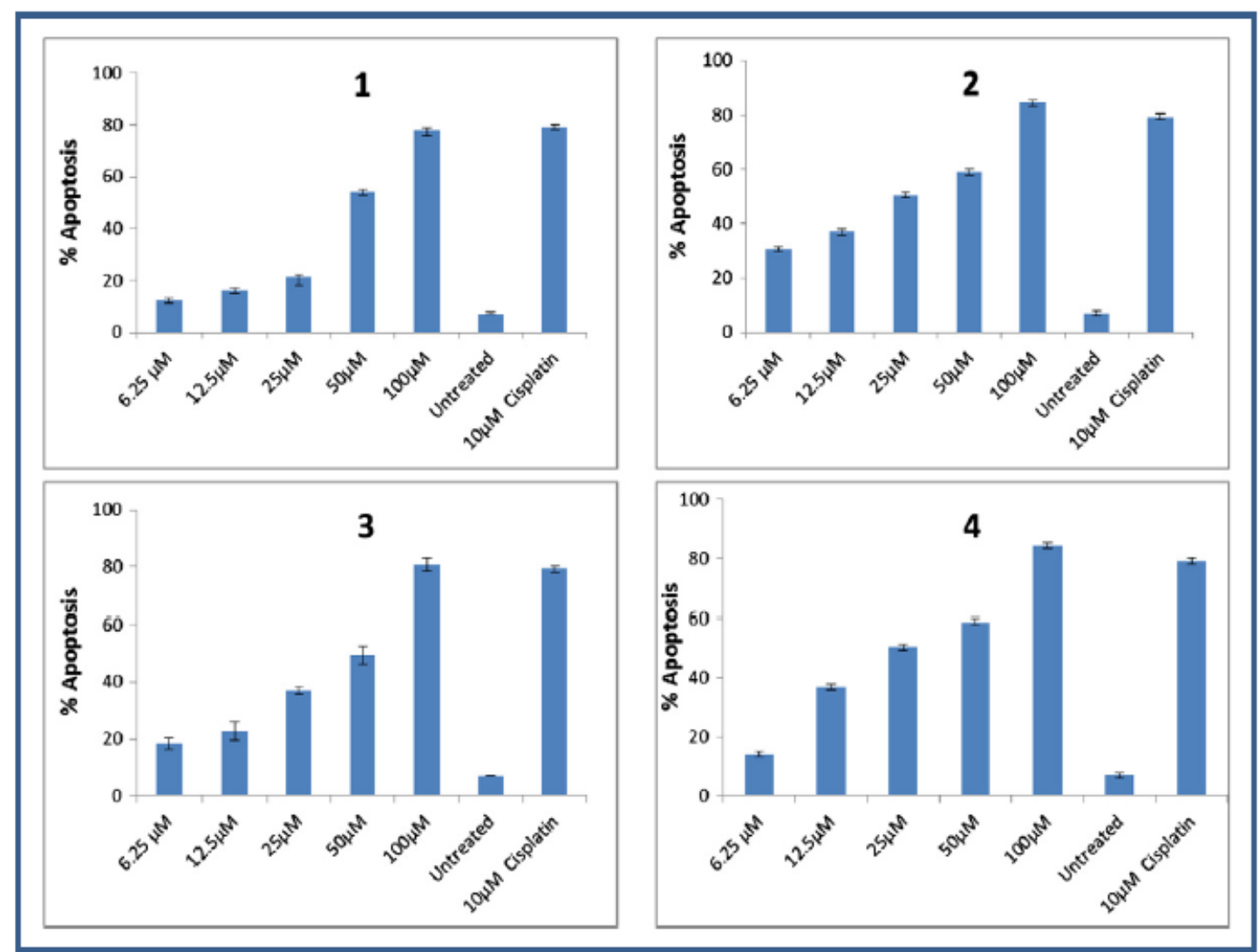

MCF-7

Fig.4. Quantification of pro-apoptotic activities of imino-phosphine complexes against MCF-7.

The imino-phosphine palladium(II) and platinum(II) complexes 1-4 proved to possess remarkable antiproliferative activities against MCF-7 and HT-29 cancer cell lines compared to the reference drug cisplatin, which returned $\mathrm{IC}_{50}$ values around $100 \mu \mathrm{M}$. Furthermore, imino-phosphine palladium(II) complexes showed superior cytotoxic activities compared to their platinum(II) counterparts. For instance, complexes 1 and 2 displayed cytotoxic effectiveness that is almost three times that of complexes 3 and 4 against MCF-7 cancer cell lines, and this could be attributed to the higher aqueous solubility of palladium(II) complexes, which allows them to dissociate readily in solution, thereby making them bio-available [45].

All the complexes generally exhibited higher cytotoxic activities against human colon (HT-29) cell line ( $\mathrm{IC}_{50}$ 29-55 $\mu \mathrm{M}$ ) compared to the human breast (MCF-7) cell line. However, the highest cytotoxic activity was observed in complex $2\left(\mathrm{IC}_{50}=29 \mu \mathrm{M}\right)$, which was approximately four times more potent than cisplatin against the two examined cancer cell lines. The general pattern observed in cytotoxicity values for the complexes across the two cell lines showed higher activities for 2 and 4. These complexes contain aniline with two methyl groups substituted at ortho-positions, making the complexes more sterically demanding compared to 1 and 3 . This trend

\section{http://repository.uwc.ac.za}


is supported by the literature which stresses the importance of steric congestion in preventing axial approach to the coordinated metal atom, thereby permitting high selectivity to DNA binding [36-39]. Furthermore, complexes 1 and 2 gave selectivity indices $\mathrm{N} 2$ against the two cell lines and their selectivity towards these cancer cell lines make them promising compounds.

The imino-phosphine ligands L1 and L2 form a 6-membered ring around the metal center, which stabilized the complexes during biological investigations, and probably resulting in the observed antitumor profiles [14]. The complexes are also square planar with metal chloride bonds in cis-position, and when considering the proposed mechanism of action of cisplatin [46,47], it is reasonable to suggest that cytotoxicity of these imino-phosphine complexes is derived from DNA binding. It is also well known that square planar metal complexes with aromatic ligands bind to DNA by intercalation, implying that the complexes have potential as intercalation agents $[48,49]$. Our initial study therefore, has shown that imino-phosphine complexes are promising antitumor agents. However, further biological investigations are needed to elucidate the intercalation modes and study the structure-activity relationship of the complexes, especially those that showed remarkable cytotoxicity profiles in order to qualify them as potential drugs.

APOPercentage was used to evaluate pro-apoptotic activity of the complexes. The assay was performed following a literature procedure [50]. In the pro-apoptotic activity of the complexes (Figs. 4 and 5), a dose dependent increase in the number of apoptotic cells was observed in HT-29 and MCF-7 cell lines treated with the complexes, suggesting that the complexes induced apoptosis against the examined cell lines.

\section{Conclusions}

We have successfully prepared and fully characterized imino-phosphine palladium(II) and platinum(II) complexes. The complexes were evaluated for the first time in vitro for their cytotoxic activity against human breast (MCF-7) and human colon (HT-29) cancer cell lines. 


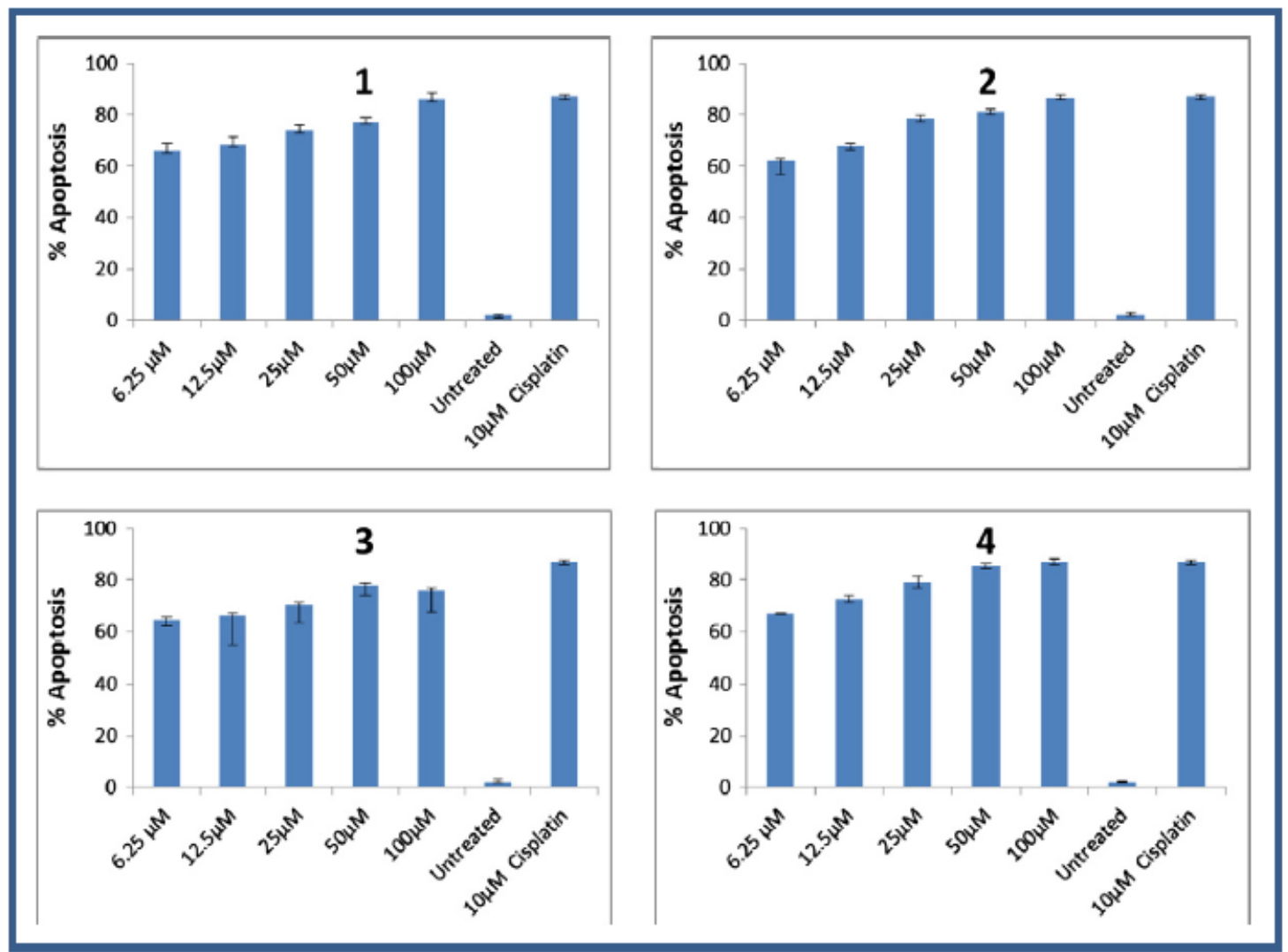

HT-29

Fig 5. Quantification of pro-apoptotic activities of imino-phosphine complexes against HT-29 cells.

The free imino-phosphine ligand did not return any appreciable activity against the examined cell lines. The complexes exhibited growth inhibitory activities that were even better than cisplatin, with the highest cytotoxic activity pronounced in complex $2\left(\mathrm{IC}_{50}=29 \mu \mathrm{M}\right)$. Complex 2 also displayed remarkable cytotoxicity and selectivity against the human breast $(\mathrm{MCF}-7)$ cell line $\left(\mathrm{IC}_{5 \mathrm{O}}=28.5 \mu \mathrm{M}\right)$ compared to complex $4\left(\mathrm{IC}_{5 \mathrm{O}}=86 \mu \mathrm{M}\right)$.

\section{Acknowledgements}

The authors are grateful for the financial support from the University of the Western Cape Senate Research and the National Research Foundation.

\section{Appendix A. Supplementary data}

Supplementary data to this article can be found online at http://dx. doi.org/10.1016/j.jinorgbio.2013.09.010. 
References

[1] J.E. Hoots, T. Rauchfuss, D.A. Wrobleski, Inorg. Synth. 21 (1982) 175-179.

[2] G.R. Newkome, Chem. Rev. 93 (1993) 2067-2089.

[3] C.A. Ghilardi, S. Midollini, S. Moneti, A. Orlandini, G. Scapacci, J. Chem. Soc. Dalton Trans. (1992) 3371-3376.

[4] J.R. Dilworth, S.D. Howe, A.J. Hutson, J.R. Miller, J. Silver, R.M. Thomson, M. Harman, M.B. Hursthouse, J. Chem. Soc. Dalton Trans. (1994) 3553-3556.

[5] T.F. Vaughan, D.J. Koedyk, J.L. Spencer, Organometallics 30 (2011) 51705180.

[6] M. Puri, S. Gatard, D.A. Smith, O.V. Ozerov, Organometallics 30 (2011) 2472-2482.

[7] K.E. Thiesen, K. Maitra, M.M. Olmstead, S. Attar, Organometallics 29 (2010) 6334-6342.

[8] S. Zhang, R. Pattacini, P. Braunstein, Organometallics 29 (2010) 66606667.

[9] R.A. Baldwin, R.M. Washburn, Organomet. Chem. 30 (1965) 3860-3866.

[10] V. Gandin, A.P. Fernandes, M.P. Rigobello, B. Dani, F. Sorrentino, F. Tisato, M.

Bjornstedt, A. Bindoli, A. Sturaro, R. Rella, C. Marzano, Biochem. Pharmacol. 79 (2010) 90-101.

[11] C. Marzano, V. Gandin, A. Folda, G. Scutari, A. Bindoli, M.P. Rigobello, Free Radic. Biol. Med. 42 (2007) 872-881.

[12] G.D. Hoke, F.L. McCabe, L.F. Faucette, J.O. Bartus, C.M. Sung, B.D. Jensen, J.R. Heys, G.F. Rush, D.W. Alberts, R.K. Johnson, Mol. Pharmacol. 39 (1991) 90-97.

[13] N. Pillarsetty, K.K. Katti, T.J. Hoffman, W.A. Volkert, K.V. Katti, H. Kamei, T. Koide, J. Med. Chem. 46 (2003) 1130-1132.

[14] A. Bacchi, M. Carcelli, M. Costa, A. Fochi, C. Monici, P. Pelagatti, C. Pelizzi, G. Pelizzi, L.M.S. Roca, J. Organomet. Chem. 593 (2000) 180-191.

[15] J. Wiedermann, K. Mereiter, K. Kirchner, J. Mol. Catal. A: Chem. 257 (2006) $67-72$.

[16] W.M. Motswainyana, M.O. Onani, J. Jacobs, L. Van Meervelt, Acta Crystallogr. C69 (2013) 209-211.

[17] G.M. Sheldrick, Acta Crystallogr. A64 (2008) 112-122.

[18] L.J. Farrugia, J. Appl. Crystallogr. 32 (1999) 837-838.

[19] L.J. Farrugia, J. Appl. Crystallogr. 30 (1997) 565-566.

[20] E.K. van den Beuken, W.J.J. Smeets, A.L. Spek, B.F. Feringa, Chem. Commun. (1998) 223-224.

[21] J. Best, J.M. Wilson, H. Adams, L. Gonsalvi, M. Peruzzini, A. Haynes, Organometallics 26 (2007) 1960-1965.

[22] M.M. Mogorosi, T. Mahamo, J.R. Moss, S.F. Mapolie, J.C. Slootweg, K. Lammertsma, G.S. Smith, J. Organomet. Chem. 696 (2011) 3585-3592.

[23] S.M. Nobre, A.L. Monteiro, J. Mol. Catal. A: Chem. 313 (2009) 65-73.

[24] N.C. Antonels, B. Therrien, J.R. Moss, G.S. Smith, Inorg. Chem. Commun. 12 (2009) 716-719. 
[25] R.E. Rulke, V.E. Kaasjager, P. Wehman, C.J. Elsevier, P.W.N.M. van Leeuwen, K. Vrieze, Organometallics 15 (1996) 3022-3031.

[26] J.C. Jeffery, T.B. Rauchfuss, P.A. Tucker, Inorg. Chem. 19 (1980) 3306-3316.

[27] S. Antonaroli, B. Crociani, J. Organomet. Chem. 560 (1998) 137-146.

[28] S. Doherty, J.G. Knight, T.H. Scanlam, M.R.J. Elsegood, W. Clegg, J. Organomet. Chem. 650 (2002) 231-248.

[29] Z. Zhang, S. Chen, X. Zhang, H. Li, Y. Ke, Y. Lu, Y. Hu, J. Mol. Catal. A: Chem. 230 (2005) $1-8$.

[30] W.M. Motswainyana, S.O. Ojwach, M.O. Onani, E.I. Iwuoha, J. Darkwa, Polyhedron 30 (2011) 2574-2580.

[31] F.H. Allen, Acta Crystallogr. B58 (2002) 380-388.

[32] H. Chiririwa, A. Muller, Acta Crystallogr. E68 (2012) m116-m117.

[33] H.A. Ankersmit, B.H. Loken, H. Kooijman, A.L. Spek, K. Vrieze, G. van Koten, Inorg. Chim. Acta 252 (1996) 141-155.

[34] K.R. Reddy, K. Surekha, G.H. Lee, S.M. Peng, S.T. Liu, Organometallies 19 (2000) 2637-2639.

[35] W.M. Motswainyana, M.O. Onani, R.A. Lalancette, Acta Crystallogr. E68 (2012) m339.

[36] A.C.G. Hotze, Y. Chen, T.W. Hambley, S. Parsons, N.A. Kratochwil, J.A. Parkison, V.P. Munk, P.J. Sadler, Eur. J. Inorg. Chem. (2002) 1035-1039.

[37] B.K. Singh, U.K. Jetley, R.K. Sharma, B.S. Garg, Spectrochim. Acta 68 (2007) $63-73$.

[38] E. Ulukaya, F. Ari, K. Dimas, E.I. Ikitimur, E. Guney, V.T. Yilmaz, Eur. J. Med. Chem. 46 (2011) 4957-4963.

[39] M.L. Conrad, J.E. Enman, S.J. Scales, H. Zhang, C.M. Vogels, M.T. Saleh, A. Decken, S.A. Westcott, Inorg. Chim. Acta 358 (2005) 63-69.

[40] E. Wong, M. Giandomenico, Chem. Rev. 99 (1999) 2451-2466.

[41] Z. Petrovski, M.R.P. Norton de Matos, S.S. Braga, C.C.L. Pereira, M.L. Matos, I.S. Goncalves, M. Pillinger, P.M. Alves, C.C. Romao, J. Organomet. Chem. 693 (2008) 675-684.

[42] T. Mosmann, J. Immunol. Methods 65 (1983) 55-63.

[43] F.M. Freimoser, C.A. Jacob, M. Aebi, U. Tuor, Appl. Environ. Microbiol. 65 (1999) 3727-3729.

[44] F. Basolo, Coord. Chem. Rev. 154 (1996) 151-161.

[45] E. Gao, C. Liu, M. Zhu, H. Lin, Q. Wu, L. Liu, Anticancer Agents Med. Chem. 9 (2009) 356-368.

[46] M.A. Fuertes, C. Alonso, J.M. Perez, Chem. Rev. 103 (2003) 645-662.

[47] Y. Jung, S.J. Lippard, Chem. Rev. 107 (2007) 1387-1407.

[48] K.E. Erkkila, D.T. Odom, J.K. Barton, Chem. Rev. 99 (1999) 2777-2795.

[49] J.G. Collins, R.M. Rixon, J.R. Aldrich-Wright, Inorg. Chem. 39 (2000) 43774378.

[50] M. Meyer, E. Magbubah, S. Kanyanda, D.J.G. Rees, BioTechniques 45 (2008) 317. 